\title{
An abscess due to Pasteurella multocida after a cat scratch: Case report and evaluation of antibiotic prophylaxis
}

\author{
Yeşim Alpay, Pınar Korkmaz, Figen Çevik, Nevil Aykın \\ Eskişehir Yunus Emre StateHospital, Department of Clinical Microbiology and Infectious Diseases, Eskişehir, Turkey
}

\begin{abstract}
Pasteurella multocida has been isolated from $50 \%$ to $70 \%$ of healthy cats and most commonly associated with acute skin and soft tissue infections following an animal bite or scratch. Location and depth of injury can lead to more serious infections such as deep tissue infections, septic arthritis and osteomyelitis. However, no predictive factor showing which wound would be infected. In our case, patient whom applied with abscess after a cat scratch and $P$. multocida was found as a causative agent. This situation has caused to review us, once more, that which cases should be taken antibiotic prophylaxis in addition to immunoprophylaxis (for rabies post-exposure prophylaxis, and anti-tetanus prophylaxis) in the first admission. Antibiotic prophylaxis should be used for 3-5 days in selected cases if they include; moderate to severe crushing injuries especially edematous form, less than 8 hours old, bone or joint penetration, hand wounds, especially emphasizes the importance of hand injuries and deep penetrations. J Microbiol Infect Dis 2014; 4(4): 159-161
\end{abstract}

Key words: Pasteurella multocida, cat scratch, antibiotic prophylaxis

\section{Kedi tırmalaması sonrası Pasteurella multocida'ya bağlı abse: Olgu sunumu}

\section{ÖZET}

Sağlıklı kedilerin \%50 ile \%70'inde Pasteurella multocida izole edilmekte ve hayvanın tırmalaması ya da ısırmasını takiben gelişen deri ve yumuşak doku infeksiyonlarına sıklıkla neden olabilmektedir. Yaralanmanın olduğu bölge ve derinliği itibariyle derin doku infeksiyonları, septik artrit, osteomyelit gibi çok daha ciddi infeksiyonlara yol açabilmektedir. Buna rağmen hangi yaranın infekte olacağını gösteren prediktif faktör yoktur. Bizim olgumuz kedi tırmalaması sonrası oluşan abse nedeniyle başvurdu ve etken olarak P. multocida saptandı. Bu durum, "ilk başvuruda immünoprofilaksiye (temas sonrası kuduz ve tetanoz profilaksisi) ilaveten antibiyoprofilaksi hangi vakalara uygulanmalı?" sorusunu bir kez daha gözden geçirmemize neden oldu. Seçilmiş vakalarda; orta ve şiddetli ezilme şeklinde yaralanmalarda özellikle ödematöz formda, yaralanmanın üzerinden sekiz saatten az bir zaman geçmişse, kemik veya eklem penetrasyonu ihtimali varsa, el yaralanmalarında, 3-5 gün süre ile antibiyoterapi önerilmekte ve özellikle el yaralanmaları ve derin penetrasyonlarda antibiyoterapinin önemi vurgulanmaktadır.

Anahtar kelimeler: Pasteurella multocida, kedi tırmalaması, antibiyotik profilaksisi

\section{INTRODUCTION}

Pasteurella multocida infections are occasionally found on the extremities of the body due to cat scratch. ${ }^{1} P$. multocida has been isolated from $50 \%$ to $70 \%$ of healthy cats and most commonly associated with acute skin and soft tissue infections following an animal bite or scratch. ${ }^{2}$ There is no predictive factor indicating which wounds may be infected. Antibiotic prophylaxis is recommended for a period of 3-5 days in selected cases. ${ }^{2}$ According to our knowledge; our case report is one of the few reports about $P$. multocida infection associated with cat scratch in Turkey.

\section{CASE}

60-year-old male patient was admitted to the Infection Diseases Clinic because of the wound on the left arm and hand caused by cat scratch four days ago. On examination, there were numerous deep line and crusted over scratches of the patient forearm and hand. There was an abscess that $2 \times 3 \mathrm{~cm}$ in size on the patient forearm, and little pus was 
presented spontaneously. In his history the patient was admitted to Emergency Department within 24 hours, immunoprophylaxis was performed by physician, but he had not received antibiotic treatment. Abscess formation developed on the third day of cat scratch. Around the holes, pain, tenderness and pruritus were seen as symptoms. The patient had no fever. On laboratory, white blood cell count was $6300 / \mathrm{mm}^{3}$, Erythrocyte sedimentation rate (ESR) was $6 \mathrm{~mm} / \mathrm{h}, C$ reactive protein (CRP) was $6.5 \mathrm{mg} / \mathrm{L}$ and routine biochemical tests were within normal limits. P. multocida was isolated from the wound culture.

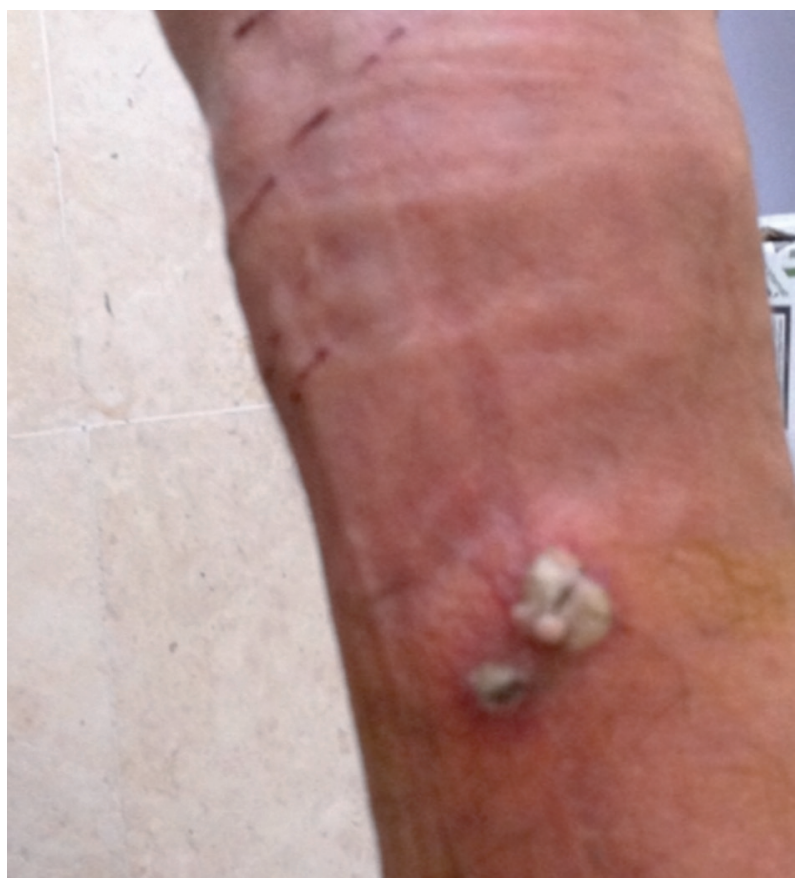

Figure 1. An abscess on the left arm caused by cat scratch

Amoxicillin-clavulanic acid $1 \mathrm{~g}$ was administered $\mathrm{q} 12 \mathrm{~h}$, and debridement of the wound performed by the physician. Finally, the patient completely recovered after ten days of therapy.

\section{DISCUSSION}

Cat bites are the second most common mammalian bites. ${ }^{1}$ While cat and dog bites often cause minor lesions that can be treated by thorough wound care if presented early, the importance of possible late complications should not be overlooked. ${ }^{3}$ Cellulitis is one of the most common infections after cat bites. Local infections are characterized by the rapid ap- pearance of erythema, warmth, tenderness, and frequently purulent drainage. $21 \%$ to $39 \%$ of cases present wound drainage. ${ }^{4}$ P. multocida is the most common microorganism in soft tissue infection due to cat bites and abscess is most common complication. ${ }^{5}$ Zong et al. ${ }^{4}$ reported an abscess due to $P$. multocida which developed at the injury site within three days after a cat bite, similar to our case.

In a review that includes 34 cases of $P$. multocida infections, reported the most common infections caused by P. multocida which are local wound infections or serious local complications include septic arthritis and osteomyelitis most commonly involving a finger or hand after a cat bite. Bacteremia, meningitis, pneumonia, brain abscess, spontaneous bacterial peritonitis, intra-abdominal abscess are the other systemic infections caused by $P$. multocida infection. ${ }^{4-12}$

Microorganisms are frequently isolated from wound infection occured by bite injuries and injuries ranged from relatively minor wounds to major injuries that included open fractures, persistent deep infection including osteomyelitis, nerve laceration, tendon laceration, or tissue loss. ${ }^{2,13}$ Antibiotic prophylaxis should be performed if bone or joint penetration is possible, especially for hand injuries and immunocompromised patient. ${ }^{14}$ We consider performing antibiotic prophylaxis because of the complications.

The antimicrobials selected for therapy of infected animal bite wounds must have activity against the components of the biting animals' oral flora, including P. multocida and its subspecies. ${ }^{15}$ Recommendations about case selection for antibiotic prophylaxis may vary. Currently recommended regimens include amoxicillin-clavulanic acid orally or ampicillin-sulbactam, carbapenems, or cefoxitin intravenously. ${ }^{16}$ However, since about more than $50 \%$ cat bite wounds become infected, most experts recommend a short course ( 3 to 5 days) of oral antimicrobial therapy. ${ }^{5}$ Antibiotherapy should cover $P$. multocida, S. aureus and anaerobes. Amoxicillinclavulanic acid is usually the first choice antibiotic. ${ }^{4,16}$ Clindamycine, doxycycline, moxifloxacine, aztreonam and macrolides are also recommended for local wound infections caused by P. Multocida. 2,16,17 Our case successfully treated with amoxicillin-clavulanic acid with surgical drainage.

As a result, there are some important factors for the risk of infection after a cat scratch; site of injury especially hands and forearm, deep location, multiple injuries neighboring bone or joint. In these 
conditions, antibiotic therapy should be started in the first admission.

\section{REFERENCES}

1. Mitnovetski S, Kimble F. Cat bites of the hand. ANZ J of Surg 2004; 74: 859-862.

2. Goldstein EJC. Bites. In: Mandell GL, Bennett JE, Dolin R eds. Mandell, Douglas, and Bennett's Principles and practice of Infectious Diseases 7th edn. Vol 2: Philadelphia, PA: Churchill Livingstone Elsevier, 2010:3911-3915.

3. Philipsen TE, Molderez C, Gys T. Cat and dog bites. What to do? Guidelines for the treatment of cat and dog bites in humans. Acta Chir Belg 2006;106:692-695.

4. Zong ZY, Gao YY, Wang XH. Subcutaneous abscess caused by Pasteurella multocida in a patient due to a cat bite. Chin Med J 2005; 118:1045-1046.

5. Benson LS, Edwards SL, Schiff AP, et al. Dog and cat bites to the hand: treatment and cost assessment. J Hand Surg Am 2006;31:468-473.

6. Kimura R, Hayashi Y, Takeuchi T, et al. Pasteurella multocida septicemia caused by close contact with a domestic cat: case report and literature review. J Infect Chemother 2004; 10:250-252.

7. Mat $\mathrm{O}$, Moenens F, Beauwens $\mathrm{R}$, et al. Indolent Pasteurella multocida peritonitis in a CCPD patient. 25 years of "cat-bite peritonitis": a review. Perit Dial Int 2005;25:88-90.

8. Rondon Berrios H, Trevejo Nunez GJ. Pets or pest: peritoneal dialysis-related peritonitis due to Pasteurella multocida. J Microbiol Immunol Infect 2010; 43:155-158.
9. Kobayaa H, Souki RR, Trust S, Domachowske JB. Pasteurella multocida meningitis in newborns after incidental animal exposure. Pediatr Infect Dis J 2009;28:928-929.

10. Kofteridis DP, Christofaki M, Mantadakis E, et al. Bacteremic community-acquired pneumonia due to Pasteurella multocida. Int J Infect Dis 2009;13:81-83

11. Rada N, Arrad B, Draiss G, et al. Pasteurella multocida: a rare cause of cerebral abscess. Med Mal Infect 2012;42:525526 .

12. Mugambi SM, Ullian ME. Bacteremia, sepsis, and peritonitis with Pasteurella multocida in a peritoneal dialysis patient. Perit Dial Int 2010;30:381-383.

13. Brook I. Management of human and animal bite wound infection: an overview. Curr Infect Dis Rep 2009; 11:389-395.

14. Yokose N, Dan K. Pasteurella multocida sepsis, due to a scratch from a pet cat, in a post-chemotherapy neutropenic patient with non-Hodgkin lymphoma. Int J Hematol 2007 ;85:146-148.

15. Goldstein EJ, Citron DM, Merriam CV, Tyrrell KL. Ceftaroline versus Isolates from Animal Bite Wounds: Comparative In Vitro Activities against 243 Isolates, Including 156 Pasteurella Species Isolates. Antimicrob Agents Chemother 2012; 56:6319-6323.

16. Stevens DL, Bisno AL, Chambers HF, et al. Practice guidelines for the diagnosis and management of skin and soft-tissue infections. Clin Infect Dis 2005; 41: 1373-1406.

17. Winner JS, Gentry CA, Machado LJ, Cornea P. Aztreonam treatment of Pasteurella multocida cellulitis and bacteremia Ann Pharmacother 2003; 37:392-394. 